\title{
Producing a Drama for the Common Good: The Theatricalization of the Crisis Discourse on Cultural Journalism
}

\author{
Maarit Jaakkola \\ ORCID: 0000-0001-9979-6157 • ResearcherID: U-1835-2017 \\ University of Tampere, Faculty of Communication Sciences \\ University of Gothenburg, Nordic Information Centre for Media \\ and Communication Research
}

Received 31 October 2017 • Revised 18 November 2017 • Accepted 202017

\begin{abstract}
This article examines the discourses in the coverage of cultural journalism and its alleged crisis. The economical, technological, cultural and social transformations of the 21st-century media landscape have been translated into a crisis narrative that is sustained even by the practitioners themselves. The journalistic coverage concerning cultural journalism in general-interest news outlets in the period 2010-2017 includes a variety of representations of the crisis in culture and cultural journalism in the Nordic countries. By analysing the crisis in journalistic approaches as an operative concept for debating the topic in the public sphere, the study traces the functions of the crisis discourse. In this study, they are considered by applying the Aristotelian concept of thaumaston, which reflects both the inevitability of a catastrophe and the opportunity to create a reaction. The crisis narrative thus could be productive by increasing the accountability and openness in journalism while staging a drama that promotes a pessimistic representation of the topic.
\end{abstract}

Keywords: crisis, theatricalization, cultural journalism, metadiscourse, public sphere.

\section{Introduction}

When they are addressed in public, or referred to as societal institutions, cultural phenomena such as cultural journalism, criticism and the arts tend to be met by a certain amount of pessimism. Cultural criticism, or the reviewing of the arts, for example, is typically thought to be dying, if not already dead, or undergoing a "permanent crisis" (Frey, 2014; see also Elkins, 2003; Elkins \& Newman, 2008; Rubinstein, 2006; Jaakkola, 2015a). Similarly, it has been observed that the professional narrative of cultural journalists, art reviewers and critics draws on this kind of cultural pessimism. As shown in previous studies, the public metadiscourse of cultural debates is to a large extent connected to the idea of a crisis: when cultural journalism is publicly addressed, it is framed by the concepts of crisis, deterioration, or less favourable development (Jaakkola, 2015a).

The articulation of a crisis in cultural journalism encompasses wide-ranging links with cultural theory, particularly the theory of criticism, the professional ideology of journalism and its connections to the democratic society, and the sociology of art. By exploring the discourse on cultural journalism through the lens of performance theory, we may learn how this crisis is constituted, staged and used to the advantage of the actors involved. Within the frame of the

(C) Authors. Terms and conditions of Creative Commons Attribution 4.0 International (CC BY 4.0) apply. Correspondence: Maarit Jaakkola, PO Box 713, SE 40530 Gothenburg, Sweden. E-mail: maarit.jaakkola@gu.se. 
sociology of professions, in which professionalism is seen as a historical project based on an ongoing struggle to maintain autonomy and integrity vis-à-vis external intervening factors (Freidson, 2001; Blank, 2007), it seems peculiar that the professional crisis is acknowledged and sustained by the practitioners themselves. The practitioners of traditional professions, such as medical doctors, lawyers, priests and teachers, would not refer to themselves by lamenting the poor foundations of their profession or exposing their inferiority to other professions. Or would they?

- The study of discourse on cultural journalism in the daily press is to a high extent connected to the idea of crisis ("the death of cultural journalism").

- Theatralization of the crisis discourse can be seen as an entry point to the public space, or a way to make the issue journalistically interesting, topical and relevant.

- Theatralization of the crisis also serves as defending the autonomy of the institutions of arts and cultural journalism, which are interconnected, and the common concern for the crisis debaters is thus the loss of autonomy of cultural journalism.

In this article, I address the professional metadiscourse of crisis and cultural journalism in the Nordic countries in order to examine its uses and gain insight into its transformative power in society and public debate. By examining the metadiscourse on the contemporary characteristics and state of cultural journalism during the second decade of the 21st century, which has so far remained unexamined in the Nordic scholarly literature, I intend to determine how the crisis is presented and dramatised in the public sphere. The theatrical approach, which according to Meyer (1992: 66) "seems almost ready-made for the media stage", may help in determining the reasons that the idea of crisis is used to address the state of cultural journalism. With the help of the concept of theatricalization, I will follow the presentations of the crisis to understand how it is staged and used to convey a message.

Specifically, I intend to find answers to the following questions: How is the idea of "crisis" presented in journalistic news coverage that discusses the contemporary cultural journalism? The object of the study is the public metadiscourse concerning cultural journalism in the public sphere of general interest, that is, the daily press created for large audiences.

The Nordic countries, or the geopolitically constructed region of "Norden" (Jukarainen, 1999), has been found to be a relatively culturally and politically homogeneous region. With their strong journalistic professionalism, state interventions and the welfare state ideology, as well as high the circulation of newspapers and high rates of newspaper reading, the Nordic countries show strong similarities in their media systems (Hallin \& Mancini, 2004) and journalism cultures (Hanitzsch, 2007), which are supported by their similar systems of journalism education (Hovden et al., 2016). In these countries, cultural journalism has a common basis and thus a similar, established tradition in producing quality dailies (Kristensen \& Riegert, 2017). Because cultural performances such as the metadiscourse explored in this article are essentially local (see e.g., Reinelt \& Roalch, 1992), it can be assumed that discussions concerning the institution of cultural journalism are rooted in a consistent definition of the phenomenon. Thus, they provide us with possibility of analysing the professional metadiscourse beyond one local or national community.

\section{Crisis and the theatricalization of discourse}

Journalism has been studied in terms of its content or according to the notions of practitioners (e.g., the professional identity of perceived changes in journalism) rather than examining journalistic self-coverage. The object of study in this article is a discourse that represents the discourse of journalism. According to Fiske (2010, 1989: 19), culture is "the active 
process of generating and circulating meanings and pleasures within a social system”, and cultural journalism refers to the journalistic process of carrying out this process within the conventional understanding of cultural journalism (for definitions, see Jaakkola 2015a). In cultural journalism, the coverage is metadiscourse because it is discourse on the discourse produced by a discursively produced object. Those involved in producing the discourse on the discursive object are part of that object. In news and feature articles, which rest, to use Gaye Tuchman's classical vocabulary, on the epistemology of the strategic ritual of the objectification of knowledge (Tuchman, 1972), journalism produces objectified presentations of itself in the public sphere. The relationship to the object of reporting, however, is not entirely disclosed; the articles do not typically position the writers as "we" or cultural journalism as "our" habitat. They elude this direct relationship by referring to sources.

The metadiscourse examined in this study is exercised in a public space that is created for relatively large audiences. The audience of general-interest daily newspapers includes all citizens within the circulation area, whereas special-interest magazines and niched online outlets try to reach readers with an initial interest in the subject area. However, they all represent public discourse about a public phenomenon. Metadiscourse is largely connected to performativity; it is produced discourse that is per se independent from whether the conditions discussed are factually true or not. In this context, the production of metadiscourse is a performance, a cultural practice and a practice of presentation in which individuals who are socially embedded in distinct sociocultural and physic-material environments establish an imaginary relationship with their conditions of existence. Hence, imagining a crisis is a performative fact based on a selected discourse, through which an actor tries to impose his or her worldviews on others in public debate.

The prevalence of the idea of crisis plays a distinct role in cultural journalism, which is a type of journalism that is based on criticality, particularly the systematised and institutionalised forms of criticism, arts criticism and reviewing. Since its beginning, modern cultural journalism has been conceived of as providing a forum of free thought and opinionmaking and an intellectual free zone manifest in the frequent occurrence of historical culture wars related to the formation of canons (see e.g., Gates, 1992). This normative ideal is still valid. For example, when the new culture chief of the regional newspaper Göteborgs-Posten in Sweden entered his post, he defined cultural journalism as 'the haven of the open mind' (Werner, 2017), which resonates with the argument that cultural journalism is a sanctuary for thoughts that cannot be expressed in other parts of the news outlet. Cultural journalism thus fulfils a fundamental function in a democratic society not only by mediating information, informed opinions, tastes and lifestyles to large audiences but also by both reflecting society and participating in its production. An important part of cultural journalism is the substance area of arts and aesthetics, which formed the core of modern cultural journalism (Jaakkola 2015a).

The word crisis is profoundly etymologically connected to cultural journalism. In the classical Greek theatre, krisis was the rigorous mental activity of judgement that was exercised by the audience and the judges, that is, kritai who dispensed verdicts about the plays. The criticism of the arts, which is the institutionalised form of publicly evaluating cultural products, is still a central ingredient of cultural journalism. Reflected in the idea of being a haven for free thought, cultural journalism is permeated by the idea of criticality. Indeed, critical cultural journalism is equated with quality cultural journalism. According to Olsen (2014), critical cultural journalism has five features, which are reflected in several discussions: it is investigative, knowledge-based, critical, independent and engaging. By “investigative", he means that journalists are interested in economic and power issues instead of artistic expression and form or the arts as an isolated area of social life. By "knowledge-based" he means that facts rather than taste should be used as guiding principle in journalism. He understands "criticality" as the norm according to which the cultural journalist creates distance from the art world, which is also reflected by "independence", according 
to which cultural journalists should set their own agendas instead of following those of the art world. By "engagement", Olsen means the ability to find relevant issues. All these features point to the journalists' ability to create a cultural (or critical) distance from the primary field of cultural production while seeking cultural proximity to the audience.

According to the Oxford English Dictionary, the term crisis is derived through Latin from the Greek root of the noun krísis, a "decision, event, turning point" and the Greek verb krinein, "to decide". The term has medical origins that refer to the turning point in a disease after which the patient's state either improves or deteriorates (Koselleck, 2006). This definition of crisis thus describes the alleged status quo of journalism as a stage in a sequence of transformational processes, thereby establishing journalism in a temporal context in which the old system can no longer be maintained. It also implies the need for change (Jaakkola, 2014). Indeed, in its most effective state, crisis is described as a surprise. According to Aristotle (350 B.C.E.), "tragedy is an imitation... of events inspiring fear or pity". The effects of a tragedy are "best produced when the events come on us by surprise", and "the effect is heightened when, at the same time, they follow as cause and effect", as "the tragic wonder will then be greater than if they happened of themselves or by accident”.

The etymology of the term crisis, which originally referred to the diagnosis of a patient's condition, reveals that the concept is not neutral but presupposes the identification of normative accounts: first, an evaluation or an assessment of a situation to determine whether a turning point exists; second, to determine the direction in which the development will proceed (Jaakkola, 2014). In other words, labelling a critical incident or a specific point in a process as a "crisis" requires a degree of judgement by the communicator. The failure of the critical function of cultural journalism has been described in terms that can be juxtaposed with the term theatricalization, which that has been adapted to the basic concept of this issue (for the definition of theatricalization, see the introduction of this special issue). Theatricalisation and the derivative term theatricality have been used in both a metaphorical and heuristical sense and as a systematised cultural model in different disciplines. It also occurs in a variety of different formulations in cultural studies (Fischer-Lichte, 1995). Theatricalisation is typically bound to the sensualisation and carnivalisation of culture (Takacs, 2017), but in the public sphere, the influential narratives of cultural processes have been the restructuration or colonisation of the public sphere (Habermas $(1991,1962)$ and represented, for example, in the forms of the colonisation of politics by the media (Meyer, 1992). Theorists of crisis, such as Agamben (2005) and Koselleck (2006), view the colonialised public sphere as a state of exception.

In general, theatricalization can be said to mean failed seriousness in which ambitions and high standards are not fully met. Takacs (2017: 22) has described theatricalization in the frame of historical studies on popular culture as "an increased emphasis on image over essence, style over substance, fantasy over reality, and emotional gesture over reasoned analysis or discourse". In the context of media and communication, similar understandings of "theatricalization" have been both detailed and limited as descriptions of processes labelled as commercialisation (see e.g., Papathanassopoulos, 2001), popularisation or the taking-over of entertainment (Kersten \& Janssen, 2016), the "dumbing down" of culture or civilisation (Ursell, 2001), or the de-professionalisation of professions (see e.g., Nygren \& Dobek-Ostrowska, 2015). Crisis discourse then could be viewed as an umbrella term for developments that are perceived as unfavourable. They are powerful because they are largely regarded as counter-processes of desirable narratives, such as the professionalisation and canonisation of different types of cultural journalism (Baumann, 2007: Lindberg et al., 2005). These terms accentuate the role of crisis in different ways and combine it with different kinds of processes. However, they have in common the observation of a process that leads to something that is less preferable from the perceiver's 
point of view. Another implication is that because the point of breakdown is close at hand, an immediate reaction is required.

In the light of the concepts discussed in this introduction, I see crisis as a staging concept. When it is used as part of discourse or a narrative it leads to a game that requires the positioning of the agents involved, which may expose some fundamental structures of how culture is epistemologically constituted within journalism or how it becomes the ontological object of cultural journalism.

\section{Method}

The data consists of newspaper articles collected from the largest newspapers, magazines and online sites in the Nordic countries - Denmark, Finland, Norway and Sweden during the period 2010-2017 ${ }^{1}$. The sample was retrieved using the digital media archive Retriever Research (Mediearkivet), a digital Nordic archive, owned by the Swedish News Agency TT, that includes material from newspapers, magazines and other Nordic news outlets. The database contains several millions of articles that are searchable as pdfs or full text (html). The major daily newspapers in each country, which are typically referred to as the metropolitan press, were included in the search, in addition to several other minor sources ranging from local papers to professional magazines.

In the archive Retriever Research, only online sources were available for the Danish and Finnish press. As for the Danish press, the results turned out to include many online articles of the daily printed press, and, as no open online archive was found to complement the results, the Danish results were limited to the online coverage only, based on an assumption that they would reflect the central national debates under the period of study. The retrieval of Finnish sources was based on a combined use of the digital archive Suomen media-arkisto ${ }^{2}$ and the archive of the Sanoma-owned daily Helsingin Sanomat, as well as the reference database for Finnish periodical articles Arto, administrated by the National Library of Finland and containing information from 350 Finnish-language magazines and journals.

Because of the similarities in the media system, the term "cultural journalism" is widely used in the Scandinavian languages instead of "arts journalism" or any other forms of "soft journalism' to describe the content published on culture pages and produced by specialised journalists (Danish and Swedish kulturjournalistik, Norwegian kulturjournalistikk and Finnish kulttuurijournalismi). To track articles that included references to this type of journalism, the search terms kulturjournalistik* for Danish, Norwegian and Swedish articles and kulttuurijournalis* for Finnish articles were used to search the digital database. The abbreviation was able to retrieve the word in different conjugations (kulturjournalistiken, kulttuurijournalismin), including all words that referred to the institution or phenomenon as an entity3.

\footnotetext{
${ }^{1}$ From 1 January 2010 to 25 September 2017.

2 The newspaper archives included the print papers and digital editions of the daily papers Aamulehti, Iltalehti, Lapin Kansa, Satakunnan Kansa and Helsingin Sanomat, as well as a number of different magazine titles.

${ }^{3}$ It was discovered that the search word kulturjournalis* would have retrieved too high an amount of data if all occurrences including a person's name (kulturjournalist, cultural journalist) were included. As in most cases, these kinds of articles would have been side notes on cultural journalism, and the focus would have been elsewhere. Hence, the search term "cultural journalism" was selected. Only the Finnish search word allowed the inclusion of persons' names (kulttuurijournalisti).
} 
The data retrieval yielded 1,787 individual articles, as summarized in Table 1. However, many articles in this sample were duplicates, as both articles with open access and articles behind the pay wall were listed in the results. Another reason is that media companies published the same story in all its different news outlets. Because leaving out articles from some newspapers while including others would have led to biased results, the duplicate articles were included in the data. In Norway, the most frequent sources were as follows: Klassekampen (81 articles) and Aftenposten (49 articles); in Sweden Dagens Nyheter (112 articles), Expressen (109 articles) and Svenska Dagbladet (89 articles); in Denmark Politiken (16 articles) and Dagbladet Information (14 articles); and in Finland Helsingin Sanomat (62 articles) and Aamulehti (28 articles).

Table 1. Description of the data

\begin{tabular}{|l|c|c|c|c|c|c|c|c|c|}
\hline & 2010 & 2011 & 2012 & 2013 & 2014 & 2015 & 2016 & 2017 & Total \\
\hline Norway & 96 & 70 & 54 & 71 & 136 & 92 & 229 & 135 & 883 \\
\hline Sweden & 112 & 88 & 76 & 84 & 83 & 72 & 71 & 46 & 632 \\
\hline Denmark & 9 & 14 & 15 & 27 & 28 & 23 & 28 & 12 & 156 \\
\hline Finland & 31 & 8 & 15 & 24 & 17 & 10 & 5 & 6 & 116 \\
\hline Total & 248 & 180 & 160 & 206 & 264 & 197 & 333 & 199 & 1,787 \\
\hline
\end{tabular}

The search revealed that the public coverage of cultural journalism was the most voluminous in Norway with 110 articles per year on average, whereas the average number of articles on cultural journalism in the public sphere was 79 in Sweden, 20 in Denmark and 15 in Finland.

The low occurrence of articles related to cultural journalism in Finland may partly derive from the combined use of sources, as no complete database for the Finnish-language articles was available. However, the databases used for the data retrieval in this study are the most central sources of newspapers and magazines produced in the language area; therefore, the articles containing the words "cultural journalism" were identified. Despite their extensive coverage, even the search in the periodicals' databases produced only eight articles that contained the words "cultural journalism", which indicates a low level of discussion about the topic in the public sphere. Another, perhaps even more plausible, explanation might be that issues of cultural journalism are typically addressed in Finnish discussions using words other than the explicit term "cultural journalism". For example, debates may be limited to criticism, reviewing or the evaluation of the quality of the arts, and the institution of cultural journalism is not explicitly semantically involved. The word 'journalism' may also have connotations that are avoided in cultural debates in some countries. Nevertheless, the presupposition of the study, according to which cultural journalism is a term with a relatively established meaning in the Nordic region, assumes that the words should be mentioned whenever the institution of journalism and culture are addressed. Similarly, when cultural journalists are discussed, the words should be used explicitly. The low number of items retrieved could relate to observations concerning the Finnish debate on culture, cultural issues and cultural journalism, which, according to public debaters with international experience, seems to be more passive than in the neighbouring countries (Koivunen, 2017; Apunen, 2009).

Nevertheless, the question of the activity and volume of a public debate seems to involve more than just counting the number of articles that refer to a distinct type of journalism. Therefore, direct conclusions about the activity of cultural discussion in the public sphere cannot be drawn based on the sample, even if the number undeniably point to the frequency at which the institutional frame occurs in public discussions. Moreover, in this study, the sample served to map 
public discourse at a general level, and the primary focus is not on comparing discussions between individual countries. The anatomy of the discussion on cultural journalism, the staging of cultural journalism in the public debate in terms of crisis and the performativity of the crisis are described in the next section.

\section{Results}

The results of the analysis of the sample of articles intended for the public's general interest supported the findings of previous studies on this topic. The results showed that the discourse on cultural journalism was tightly linked to the idea of non-preferred or notorious change (see Constantopoulou, 2016; Frey, 2014; Jaakkola, 2015b). The number of articles about the crisis indicates that it is a reoccurring frame. In Norway, 261 articles (30\%) were connected to the idea of crisis; in Sweden the number was 114 (18\%) and in Denmark it was 49 (31 \%). In Finnish newspapers, 57 articles (49\%) were about the crisis.

Regarding semantics, the headings of articles on cultural journalism highlighted crisis, death, tragedy, threat and survival: "death", "crisis", "struggle", "worry", "anxiety" and "longing" were frequent word choices. The headings typically expressed a lack of hope: "The die is cast", "Who needs a critic" and "First they outsourced sports". In addition, the problems in cultural journalism were often denoted in the headings: "lack of passion", "lack of enthusiasm", "filter bubble", "reality debate gone astray", "uncriticality" and "prostitute journalism". The same descriptions were circulated across different countries, such as the sentence appropriated from Mark Twain: "the rumours of the death of cultural journalism are greatly exaggerated", which was found in the Norwegian, Danish and Finnish articles in the sample.

The leading Finnish newspaper Helsingin Sanomat dedicated a series of articles to examining the changes in cultural journalism, which had finished before the period of study. In the summarising article, all the problems related to the production structure were discussed according to different areas of arts and culture: film, music, games, fashion, television, literature and architecture. The series of articles in Helsingin Sanomat exposed several problems in cultural journalism (HS:n sarja nosti esïn monia kulttuurijournalismin ongelmia, 28 May 2010). The problems described included the structural characteristics that undermine journalistic integrity in the production of cultural journalism (e.g., film distributors and importers tend to offer journalists pre-paid travels to make interviews and 'goodie bags' are a normalised perquisite in the fashion field). Many articles pointed to the diminishing number of reviews in cultural journalism, which has led to storylines that emphasise individual cultural producers and their celebrity status instead of the focus on content and its quality, which is the function of a review. This series of articles presented a systematic analysis of the crisis approach by addressing long-standing structural problems rather than raising an alarm about the perceived abrupt change.

A common starting point for the coverage on cultural journalism was the opinion that because cultural journalism had never managed to draw the public's attention, it should thus be discussed more frequently. For example, in the Swedish Svenska Dagbladet, Lisa Irenius remarked, "the future of cultural journalism is to an overwhelming extent discussed with risks as starting point, rather than the possibilities", and "cultural journalism is never in the focus when seminars about the digital development are organized" "This is how the future cultural journalism looks like", Så blir framtidens kulturjournalistik, 31 May 2015). Against this backdrop, the contributions of culture newsrooms to the cultural debate, which often only address cultural journalism in the public space, seem to be mere activism performed to strive for a better future.

This approach to the crisis seems to resonate well with the public discussion and research on the media. In addition to the status of cultural journalism, the 21st-century media have been discussed extensively with regard to crisis, change and renewal in terms of the 
professional crisis in content production, the change in professional values and identities (see e.g., Nygren \& Dobek-Ostrowska, 2015), the economic crisis in the funding of journalism (see e.g., Kaye \& Quinn, 2010) and the socio-cultural crisis based on the altered social functions of journalism and media in society (see e.g., Peters \& Broersma, 2017). However, in addition to the crisis frame, the results clearly showed a clear positive strain in many articles in the sample. Cultural journalism was either covered by addressing its "quality", "level", "renewal", "modernization", "digitalization" or future intentions and ambitions of the media. For example, the media will "focus on the reenlivening of culture", "recruit new employees", innovate "new forms of cultural journalism" and launch "study programs for cultural journalists". Indeed, "culture will be reconquered". Moreover, diligent attention is paid to such efforts as if the "positive" developments would occur without question. The main message of all these types of news articles is that culture and cultural journalism are needed. They are about taking cultural journalism seriously despite difficult conditions and challenges. By sharing the characteristics in their framing, these articles appeared to present a counter-argument against the implicit assumption that as a journalistic "beat", culture is expendable.

In other words, the results showed both supporting and contesting positions, both of which related the content to the idea of crisis as a turning point. Crisis works as a staging concept that bridges the shortcomings of the past and visions of future. Discussing a crisis resembles living through a thaumaston, which reflects both the inevitability of a catastrophe and the opportunity to create a reaction. In Aristotle's Poetics, pity and fear serve as the basis for tragedy to produce a catharsis at the end of a drama. According to Koselleck (2006: 374), the term crisis "takes hold of old experiences and transforms them metaphorically in ways that create new expectations". This transformation is more than metaphorical because it has 'real-world' consequences that urge action.

In setting up the crisis in the public stage, the following opinions about the status of cultural journalism were expressed in the sample articles:

Culture is and will continue to be a low-priority issue in journalism. According to the utterances in the press coverage, culture is easily disregarded in times of economic scarcity and re-structurations in media organisations, or it is rather passively ignored by not being invested in by the media organisations. There is, in other words, a crisis, but no one is interested. It is "only culture", so why care? This statement is particularly fuelled by real changes in which the position of cultural journalism has undeniably deteriorated; during the research period, several culture newsrooms were closed down in the Nordic countries, freelancers were hired, they protested against media companies or newsrooms presented strategies in which culture was not included.

Cultural coverage is under threat. This statement underpins the fight for life or death. The threat might come from various directions: it might be click journalism, or "clickocracy", commercial pressures, a shift in political power (e.g., a "Donald Trump" or a governmental minister) or elitism among cultural journalists. A central concern is that culture is not saleable and that culture can hardly be made profitable at least not without compromising what is referred to as quality content. With regard to relatively limited audiences, the cultural sector has never been a lucrative business, but several factors are now contributing to its change. For example, during the period of study, there was much discussion in the sample countries about user-paid content specifically that if nobody were willing to pay for culture its existence would be threatened under the contemporary conditions of the market economy.

Cultural journalism has already changed and not necessarily for the better. This opinion was expressed in a conglomerate group of discourses that assessed the experienced or perceived development of cultural journalism. They conveyed a sense of deterioration rather than making a clearly structured argument. This opinion implies that the turning point in the crisis process has already passed. The existing coverage has decreased, is insufficient, cultural journalists and 
reviewers have become less critical or culture editors either overestimate or underestimate their readers. The reason for this assessment may remain unclear, but its impetus is nostalgia for the old days, the desire for a better future, or simply being unsatisfied with the contemporary conditions in which cultural journalism is produced.

In all these statements of opinion, the rules of discourse govern a game in which some social groups are actors and others are spectators. In the metadiscourse, two dimensions reoccur throughout the texts. The first dimension deals with the identification of the origins of discourse in which the speaker's point of view was predominant. This dimension concerns a sense of belonging, membership in or inclusion from the speaker's point of view. It concerns whether cultural journalism is conceived of as part of a wider field in journalism and media or whether it is a specific field in its own right. The first alternative seeks similarities between cultural journalism and the rest of the journalism or media field, whereas the second alternative tends to emphasize the characteristics that distinguish cultural journalism from other types of journalism or media. A general distinction seems to exist between those who identify with the "media people", that is, staff writers and employees in media organisations, and those who feel outside the power fields of the media, that is, artists.

The second dimension is related to the origin of the threat that is crucial to the idea of crisis. The locus of crisis refers to the place in which the crisis can be found. This dimension often deals with "them", in contrast to "us", by perceiving threats as either external or internal. External threats include "click" journalism and commercial pressures in journalistic production, which are foreign to the internal rules of critical cultural production. Internal threats include low, self-set standards of quality, conservatism, and the fear of change.

The cultural field is so multi-faceted that the number of different combinations of the distinctions between these two dimensions is very high. Moreover, the positionings are constantly in flux. However, from the positionings of "we" and "them", it is possible to connect to the main opinions described above, and engagement means involvement in the collective staging of a crisis that is the driving force of the public explosion in cultural issues. Indeed, in the discourse on culture, individuals are typically seen as heroic figures embarking on a fight, struggle or (cultural) war, which is evident in the frequent occurrence of the expression "fight for culture" (kampen om kultur, kulturkampen) in the sample articles. In one article, Åsa Linderborg, the culture chief of the Swedish Aftonbladet, asserted, "culture sections that spread the light of a fragrance candle will never gain relevance" (“Culture is”, Kultur är, 25 March 2017).

\section{Discussion}

Nordic scholars who discuss cultural journalism have contradicted the crisis narrative and deemed it counterproductive if not partly misleading (Knapskog \& Larsen, 2008; Kristensen \& Riegert, 2017; Kristensen, 2010). In recent decades, the volume of cultural coverage in the daily newspapers has significantly increased. Moreover, as online editions of the news outlets have been developed, better conditions for cultural coverage have been created in online publishing. In addition, journalistic thinking, supported by several layout and format re-designs and organisational re-structurations in media organisations, has contributed to increasing the quality of the journalistic product. The number of titles of special-interest magazines in the sphere of arts and culture has been relatively stable in the present decade (See e.g., Jaakkola, 2015a; Purhonen et al., 2017; Kristensen, 2010). The boundaries between different forms or fields of arts (Purhonen et al. 2017; Jaakkola, 2015a) and between different subtypes of culturally oriented journalism (Kristensen \& From, 2012) have been observed to have blurred, which was one source of the alarming debates. To complicate the mediascape further, in the new millennium, a range of new, diverse channels for bottom-up cultural debate and coverage have emerged, which remain under- 
researched, including the blogosphere, microblogs (twitosphere) and other userspheres that are enabled by social networking sites such as Facebook and Instagram.

However, with regard to the persistence of the crisis discourse, we must note that the crisis narrative and the theatricalization of the crisis, which constitute performative actions in the public sphere, do perform important functions. The analysis of the articles published in the Nordic countries, revealed at least three fundamental functions to which the aspects discussed above can be subordinated.

First, the view that cultural journalism is a problematic area involves an identification that aims at positioning the institution not only for the audiences external to it but also for the social groups involved in its production. Crisis discourse serves to relate cultural journalism to other areas of journalism and to society in general. As an area that has typically been marginally positioned in journalism and society and has suffered from the ambiguous definition of the word "culture", there has been a distinct need, which was expressed in the early textbooks on cultural journalism, to justify the affiliations of cultural journalism to general or mainstream journalism and thus to democracy (Hansen, 1977; Loman et al., 2007; Riegert \& Roosvall, 2017).

Second, the crisis discourse is a discourse about the quality of cultural journalism. In particular, because the deterioration of quality has gained attention, it is typically the centre of discussion. Unlike other types of journalism, cultural journalism and similar forms of journalism, such as literary journalism and lifestyle journalism, has been regarded as a form of art, in which the literary qualities of the writing are valued compared with the standardised and impersonalised form of news journalism, which is the predominant form. For example, in contrast to political, economic, environmental and foreign affairs journalism, in cultural journalism the subjective input typically takes precedent over the news-making aspect. To address cultural journalism in the frame of crisis thus marks the attempt to discuss and ensure its quality.

Third, the objective of the crisis discourse is to enhance the working conditions for cultural journalists to attain the ideals of quality of cultural journalism. Crisis discourse can thus be seen as an attempt to create better conditions for work and action. This kind of strain presents activism in which culture and cultural journalism appear in the public sphere as "weaker" agents that have to be defended against the Goliaths of news journalism, the market or other intrusive factors that are seen as risks to the inner logics of culture.

With regard to these basic, profoundly interconnected functions of the crisis discourse in the public sphere, the persistence of such discourse may to some degree be better understood. In effect, addressing the crisis does not concern addressing the actual developments within the media landscape, even if their influence cannot be denied, as much as addressing the worst and best scenarios in order to sustain the integrity and autonomy that are necessary preconditions for cultural production. In cultural production, the risk of reducing art and culture to their material conditions is always at stake (Brandellero \& Kloosterman, 2010). By addressing the questions of content and quality, cultural producers are able to establish internal rules that create conditions in the external environment to allow autonomy and integrity. In the case of journalism, however, the crisis discourse also serves to contribute to increased accountability as structural or internal problems are exposed and publicly discussed.

Moreover, both culture and media are high-threshold issues that need to be made journalistically interesting in order to place them on the public agenda although for different reasons. As a process, culture contests the journalistic patterns that are manifest in news values which favour abrupt changes, events, persons and concrete matters rather than slow, gradual, enduring processes. For the media, reporting issues that need self-reflection and openness, even if accountability is officially endorsed in discourse about the quality of journalistic culture and 
practice, is a complicated question. Issues regarding the activities of the media are often considered in only professional magazines instead of being discussed in the public sphere for the general interest of large audiences, which often requires that the coverage of self-covering issues is a distinct reason for placing them on the agenda. It is not too unrealistic to think that the crisis frame has been adopted in order to make culture topical, interesting and thus relevant as a journalistic issue. It then functions as an entry point into the public discussion (Jaakkola 2015b). Simultaneously, the entry into public discussion is part of the self-interested behaviour of participants involved in the production of the discourse (Fengler \& Ruß-Mohl, 2008).

However, the semantical flexibility of the basic concepts underlying the discussionculture, quality of content and work, and as discussed above, the concept of crisis and its theatricalization-may be elusive unless it is anchored in a specific context ${ }^{4}$. Because of the possibility of multiple parallel definitions that denote very different semantic extensions of the term, the intangibility of the underlying concepts challenge rational deliberations in public about the cultural institution of cultural journalism and its related issues. In this ambiguous discursive sphere, crisis, which points to a single original event in a chain of events, appears to be an appropriate anchoring point for communication. This anchoring may concern not only the discussion of cultural journalism but also other cultural issues, which tend to oscillate between the opposite but complementary poles of cultural and democratic objects and commercial and market objects (Eide \& Knight, 1999). In this dynamic landscape of competing notions that are sometimes complementary and sometimes conflicting, the simplicity of crisis as a chronologically and spatially defined point of reference partly explains journalism's affinity for easily definable questions and issues instead of addressing concerns at the institutional level.

\section{Conclusions}

This analysis of journalistic general-interest coverage in the institution of cultural journalism indicates that the idea of crisis provides a fruitful project for discussions that otherwise would not fulfil the journalistic criteria for being interesting, topical or relevant. With the help of the crisis discourse, culture is being pushed forward from the periphery towards the centre. The ultimate threat to society includes the question of what would happen if culture were taken away from us.

To some extent, crisis discourse is part of the definition of what is meant by quality cultural journalism, cultural communication and cultural work in the wider sense. The agents involved in cultural communication are supposed to be passionately interested in the issues they address and to fight for the common good with which culture is synonymous. That is the reason that the crisis discourse seems a natural fit with the cultural journalist's parlance. When the common cultural fight seems stagnated, it is an equally "natural" action to react to the shortcomings and threats, to resume the cultural fight that constitutes that grand drama that is the driving force of the cultural public sphere.

The public sphere, which is affected by general-interest newspapers and specialinterest periodicals, is not the only space in which reflections on the institution of cultural journalism and its constitutive agents occur. Many statements concerning these reflections are documents that fall into the category of grey literature, which consists of materials produced in

\footnotetext{
${ }^{4}$ For example, according to Raymond Williams (1976), because culture is one of the most complicated words in the modern English language, it needs to be defined in every context. Similarly, quality is a multidiscursive concept that is used in several different approaches and definitions (in the framework of journalism, see Arnold, 2008).
} 
and by organisations outside the traditional commercial or academic publishing and distribution channels (Schöpfel, 2010). Such materials are also orally produced in encounters that are not recorded or documented, such as conferences, seminars, workshops, public discussion events, informal discussions etcetera. The discourse that is historically recorded is not necessarily representative of the professional practitioners' discussions and views in a certain period. However, it can be said that the issues that are assessed as interesting and relevant in a democracy are and should be addressed by the press and media. Moreover, the discussions recorded on these platforms must reflect current issues in the professional field.

\section{Acknowledgements}

This research did not receive any specific grant from funding agencies in the public, commercial, or not-for-profit sectors.

\section{References}

Agamben, G. (2005). State of exception. Chicago: The University of Chicago.

Apunen, M. (2009). Kulttuurijournalismin muistolle [Cultural journalism in memoriam]. Aamulehti.

Aristotle (2017). Poetics. http://classics.mit.edu/Aristotle/poetics.1.1.html. Accessed 27.9.2017.

Arnold, K. (2008). Qualität im Journalismus: ein integratives Konzept [Quality in journalism: An integrative concept]. Publizistik, 53(4), 488-508.

Baumann, S. (2007). Hollywood highbrow: From entertainment to art. Princeton, Woodstock: Princeton University Press.

Blank, G. (2007). Critics, ratings, and society: The sociology of reviews. Lanham: Rowman \& Littlefield Publishers.

Brandellero, A. M. C., \& Kloosterman, R. C. (2010). Keeping the market at bay: Exploring the loci of innovation in the cultural industries. Creative Industries Journal, 3(1), 61-77.

Constantopoulou, Ch. (2016). Introduction - narratives of crisis: Myths and realities of the contemporary society. French Journal of Media Research, 5/2016.

Eide, M., \& Knight, G. (1999). Public/private service: Service journalism and the problems of everyday life. European Journal of Communication, 14(4), 525-547.

Elkins, J. (2003). What happened to art criticism? Chicago: Prickly Paradigm Bristol University Presses.

Elkins, J., \& Newman, M. (Eds.) (2008). The state of art criticism. New York: Routledge.

Fengler, S., \& Ruß-Mohl, S. (2008). Journalists and the information-attention markets: Towards an economic theory of journalism. Journalism, 9(6), 667-690.

Fisher-Lichte, E. (1995). Introduction: Theatricality - a key concept in theatre and cultural studies. Theatre Research International, 2O(2), 85-90.

Fiske, J. (2010). Understanding popular culture (2 ${ }^{\text {nd }}$ ed.). London and New York: Routledge. 
Freidson, E. (2001). Professionalism: The third logic. Cambridge: Polity Press.

Frey, M. (2014). The permanent crisis of film criticism: The anxiety of authority. Amsterdam: Amsterdam University Press.

Gates, H. L. Jr. (1992). Loose canons: Notes on the culture wars. New York and Oxford: Oxford University Press.

Habermas, J. (1991). Structural transformation of the public sphere: An inquiry into a category of bourgeois society. New York: MIT Press.

Hallin, D. C., \& Mancini, P. (2004). Comparing media systems: Three models of media and politics. New York: Cambridge University Press.

Hanitzsch, T. (2007). Deconstructing journalism culture: Toward a universal theory. Communication Theory, 17, 367-385.

Hansen, E. H. (1977). Kulturjournalistik [Cultural journalism]. Copenhagen: Hernov.

Hovden, J. F., Nygren, G., \& Zilliacus-Tikkanen, H. (Eds.) (2016). Becoming a journalist: Journalism education in the Nordic countries. Gothenburg: Nordicom.

Jaakkola, M. (2014). Dismantling the crisis of journalism: Outline of an analytical approach. Teaching Journalism and Mass Communication, 4(2), 1-14.

Jaakkola, M. (2015a). The contested autonomy of arts and journalism: Change and continuity in the dual professionalism of cultural journalism. Tampere: Tampere University Press.

Jaakkola, M. (2015b). Witnesses of a cultural crisis: Representations of media-related metaprocesses as professional metacriticism of arts and cultural journalism. International Journal of Cultural Studies, 18(5), 537-554.

Jukarainen, P. (1999). Norden is dead - long live the eastwards-faced Euro-North: Geopolitical re-making of Norden in a Nordic journal. Cooperation and Conflict, 34(4), 355-382.

Kersten, A., \& Janssen, S. (2016). Trends in cultural journalism: The development of film coverage in crossnational perspective, 1955-2005. Journalism Practice, 11(7), 840-856.

Knapskog, K., \& Larsen, L. O. (2008). Kulturjournalistikk: pressen og den kulturelle offentligheten [Cultural journalism: The press and the cultural public sphere]. Oslo: Scandinavian Academic Press.

Koivunen, A. (2017). Kulturjournalistikens ödestimme [The destiny of cultural journalism]. Hufuudstadsbladet, 21 July 2017.

Koselleck, R. (2006). Crisis. Journal of the History of Ideas, 67, 357-400.

Kristensen, N. N. (2010). The historical transformation of cultural journalism. Northern Lights: Film \& Media Studies Yearbook, 8(1), 69-92.

Kristensen, N. N., \& Riegert, K. (eds.) (2017). Cultural journalism in the Nordic countries. Gothenburg: Nordicom.

Kristensen, N. N., \& From, U. (2012). Lifestyle journalism: Blurring boundaries. Journalism Practice, 6(1), 26-41.

Lindberg, U., Gudmundsson, G., Michelsen, M., \& Weisethaunet, H. (2005). Rock criticism from the beginning: Amusers, bruisers and cool-headed cruisers. New York: Peter Lang. 
Loman, R. Sjöberg, B., \& Vulovic, J. (2007). Kulturjournalistikens grunder [The foundations of cultural journalism]. Lund: Studentlitteratur.

Meyer, T. (2002). Media democracy: How the media colonize politics. Cambridge: Polity Press.

Nygren, G., \& Dobek-Ostrowska, O. (Eds.) (2015). Journalism in change: Journalistic culture in Poland, Russia and Sweden. New York: Peter Lang.

Olsen, T.A. (2014). Kritisk kulturjournalistikk [Critical cultural journalism]. Oslo: Cappelen Damm.

Papathanassopoulos, S. (2001). Media commercialization and journalism in Greece. European Journal of Communication, 16(4), 505-521.

Peters, C., \& Broersma, M. (Eds.) (2017). Rethinking journalism again: Societal role and public relevance in a digital age. New York and London: Routledge.

Purhonen, S., Heikkilä, R., \& Hazir, I. K. (2017). The grand opening? The transformation of the content of culture sections in European newspapers, 1960-2010. Poetics, 62, 29-42.

Reinelt, J.G., \& Roach, J.R. (Eds.) (1992). Critical theory and performance. Ann Arbor, MI: University of Michigan Press.

Riegert, R., \& Roosvall, A. (2017). Cultural journalism as a contribution to democratic discourse in Sweden. In: Kristensen, N.N. \& Riegert, K. (Eds.): Cultural journalism in the Nordic countries. Gothenburg: Nordicom, pp. 89-108.

Rubinstein, R. (Ed.) (2006). Critical mess: Art critics on the state of their practice. Lenox: Hard Press Editions.

Schöpfel, J. (2010). Towards a Prague definition of grey literature. Twelfth International Conference on Grey Literature: Transparency in Grey Literature. Grey Tech Approaches to High Tech Issues. Prague, 6-7 December 2010, Czech Republic, pp. 11-26.

Takacs, S. (2015). Interrogating popular culture: Key questions. New York and London: Routledge.

Tuchman, G. (1972). Objectivity as strategic ritual: An examination of newsmen's notions of objectivity. American Journal of Sociology, 77(4), 660-679.

Ursell, G. D. M. (2001). Dumbing down or shaping up? New technologies, new media, new journalism. Journalism, 2(2), 175-196.

Werner, B. (2017). Kultursidan som det öppna sinnets fristad [Culture pages as the haven for the open mind]. Göteborgs-Posten, 13 October 2017.

Williams, R. (1976). Keywords: A vocabulary of culture and society. New York: Oxford University Press. 